\title{
Illékony nitritszármazékok („popperek”) által okozott methaemoglobinaemia
}

\author{
Bakos Ágnes dr. - Bátyi Anna dr. \\ Péterfy Kórház-Rendelőintézet és Manninger Jenő Országos Traumatológiai Intézet, \\ Sürgősségi Belgyógyászat és Klinikai Toxikológiai Osztály, Budapest
}

\begin{abstract}
A methaemoglobinaemia az oxigén szállítására képtelen methemoglobin szintjének kóros emelkedését jelenti a vérben, ami jelentős szöveti oxigénhiányt okozhat, súlyos, akár életveszélyes tünetekhez vezethet. Methaemoglobinaemiát számos, oxidáló hatású exogén anyag idézhet elő, ezek közé tartoznak a partidrogként használt alkil-nitritek, az ún. „popperek” is. A „poppereket” korábban „alacsony rizikójú” drogként tartották számon, azonban számos esetet közöltek, amikor súlyos, időnként fatális kimenetelú methaemoglobinaemiát okoztak. A folyadékok gőzének belélegzése euforizáló, szexuálisvágy-fokozó és simaizom-lazító hatású, ezért a „popperek” igen népszerűek a homo- és biszexuális férfiak körében, de fiatal felnőttek és tinédzserek is használják. A folyadékok szájon át való fogyasztása különösen veszélyes. A szerzők két esetet ismertetnek, amelyekben a „popperek” használatát követően methaemoglobinaemia alakult ki. Mindkét betegnél, a jó általános állapot mellett, centrális és perifériás cyanosis tüneteit észlelték. Az alkalmazás módja (inhaláció/lenyelés), a methaemoglobinaemia súlyossága (16,4\% és $57 \%$ ) és a terápia eltérő volt a két betegnél. Az első beteg oxigén adása és tüneti kezelés mellett gyógyult, a másodiknál antidotum (metilénkék) adására is szükség volt. Mindketten panaszmentesen távoztak a kórházból. A szerzók célja az volt, hogy felhívják a figyelmet az illékony alkil-nitrit-származékok által okozott methaemoglobinaemiára, annak felismerésére, kezelésére, és bemutassák azok kevésbé ismert szövődményeit is.

Orv Hetil. 2021; 162(8): 306-313.
\end{abstract}

Kulcsszavak: „popperek”, alkil-nitritek, methaemoglobinaemia, metilénkék

\section{Methemoglobinemia caused by volatile nitrite derivates ('poppers')}

Methemoglobinemia means the abnormally elevated level of methemoglobin in the blood, which is incapable of oxygen transport, accordingly it can cause significant tissue hypoxia, leading to severe or even life-threatening clinical symptoms. Several exogen oxidative agents can induce methemoglobinemia, including alkyl-nitrites which are also used as party drugs, the so-called 'poppers'. The 'poppers' were previously considered 'low-risk' drugs, however, several cases have been published when they caused severe, sometimes fatal methemoglobinemia. Inhaling vapours from liquids has euphoric, smooth-muscle relaxing and aphrodisiac effects, therefore 'poppers' are extremely popular among gay and bisexual men but also used by young adults and teenagers. Oral consumption of the fluids is particularly dangerous. The authors present two cases when methemoglobinemia developed after 'poppers' usage. Both patients were in good general condition and symptoms of central and peripheral cyanosis were detected. The method of application (inhalation/ ingestion), the severity of methemoglobinemia (16,4\% and 57\%) and the treatment were different in the two patients. The first patient recovered with inhalation of oxygen and symptomatic treatment; the second patient required administration of antidote (methylene blue). Both patients left the hospital without complaints. The authors' aim was to attract attention to methemoglobinemia caused by volatile alkyl-nitrites, its recognition, treatment and to present their lesser-known complications.

Keywords: 'poppers', alkyl-nitrites, methemoglobinemia, methylene blue

Bakos Á, Bátyi A. [Methemoglobinemia caused by volatile nitrite derivates ('poppers')]. Orv Hetil. 2021; 12(8): 306-313.

(Beérkezett: 2020. augusztus 9.; elfogadva: 2020. szeptember 5.) 


\section{Rövidítések}

cGMP = (cyclic guanosine monophosphate $)$ ciklikus guanozinmonofoszfát $; \mathrm{EKG}=$ elektrokardiográfia; $\mathrm{FDA}=($ Food and Drug Administration) az Amerikai Egyesült Államok Élelmiszer- és Gyógyszer-engedélyeztetési Hivatala; G6PD = glükóz6-foszfát-dehidrogenáz; GOT = glutamát-oxálacetát-transzamináz; GPT = glutamát-piruvát-transzamináz; $\mathrm{Hb}=$ hemoglobin; $\mathrm{HHb}=$ deoxihemoglobin; $\mathrm{IV}=$ infravörös; $\mathrm{NAC}=$ $\mathrm{N}$-acetil-cisztein; $\mathrm{NAD}^{+} / \mathrm{NADH}=$ nikotinamid-adenin-dinukleotid/annak redukált formája; $\mathrm{NADP}^{+} / \mathrm{NADPH}=$ nikotinamid-adenin-dinukleotid-foszfát/annak redukált formája; NO = nitrogén-monoxid; $\mathrm{MAO}-\mathrm{A}=$ monoaminoxidáz- $\mathrm{A} ;$ metHb = methemoglobin; OCT $=$ (optical coherence tomography) optikaikoherencia-tomográfia; $\mathrm{O}_{2} \mathrm{Hb}=$ oxihemoglobin; $\mathrm{PDE}=$ (phosphodiesterase) foszfodiészteráz; $\mathrm{SaO}_{2}=\mathrm{az}$ artériás vér oxigénszaturációja; $\mathrm{SpO}_{2}=$ pulzoximéterrel mért oxigénszaturáció; $\mathrm{V}=$ vörös

A „popperek” partidrogként használt, alkil-nitrit- (amil-, butil-, izobutil-, izopropil-nitrit) származékokat tartalmazó, édeskés szagú, színtelen vagy enyhén sárgás színú, illékony folyadékok. Első képviselőjük az angina pectoris kezelésében alkalmazott amil-nitrit volt. Elnevezésük onnan származik, hogy az amil-nitritet eredetileg hálóba zárt üvegkapszulában hozták forgalomba, amelynek felnyitása jellegzetes pattanó hangot („popping sound”) adott. Használatuk fellendülése az 1960-as években kezdődött, amikor az amil-nitrit receptkötelességét az FDA egy időre felfüggesztette; ezt követően vásárlásának jelentős növekedését észlelték, fóként a fiatal, egészséges emberek körében. Euforizáló, szexuálisvágy-fokozó és simaizom-lazító hatása miatt igen népszerúvé vált a homo- és biszexuálisok között, de fiatal felnőttek és tinédzserek is használták $[1,2]$. Az FDA később visszavonta rendelkezését, ami az egyéb, hasonló hatású, de nem receptköteles alkil-nitrit- (butil-, izobutil-, majd izopropilnitrit ) származékok elterjedéséhez vezetett.

A ,popperek” számos országban szabadon árusíthatók, bizonyos országokban azonban árusításuk illegális, így a törvényi szabályozás megkerülése érdekében interneten, sex-shopokban, bárokban szobaillatosítóként, videófej-tisztítóként, bőrtisztítóként, 10-30 ml-es barna üvegekben, színes feliratokkal, különböző neveken (Rush, Fist, Quick Silver, TNT, XXX-rated stb.) kerülnek eladásra. 2006-ban az Egyesült Királyságban az izobutil-nitritet karcinogénné nyilvánították, és az izobutilnitritet tartalmazó készítmények árusítását Európában betiltották. A „popperek” Magyarországon nem tartoznak az elterjedt drogok közé. Nem szerepelnek a kábítószerlistán, de az amil-nitrit gyógyszerként vényköteles, így vény nélküli birtoklása illegálisnak minősül. Gőzeiket közvetlenül az üvegcséből, vagy zsebkendőre, vattára, gézlapra cseppentve, vagy nem égő cigaretta végét a folyadékba merítve inhalálják [3-8]. Hatásuk gyorsan kialakul, és általában néhány percig tart.

$\mathrm{Az}$ inhaláció mellett szájon át való véletlen vagy szándékos fogyasztásuk [8-13], illetve intravénás alkalmazá- suk [14] is előfordul. Gyakran alkohollal, más drogokkal, gyógyszerekkel kombinálják óket [2, 8-13].

A szerzók két olyan esetet mutatnak be, amikor a „popperek” használata során methaemoglobinaemia alakult ki; ismertetik annak tüneteit, diagnózisát és kezelését, illetve irodalmi adatok alapján áttekintik az élvezeti szerként használt alkil-nitrit-származékok egyéb szövődményeit is.

\section{Esetbemutatások}

\section{Elsö eset}

A 69 éves hypertoniás, refluxbetegségben, feltehetően hyperurikaemiában szenvedő és urológiai kezelés alatt álló férfit fogorvosa utalta ambulanciánkra sápadtság, verejtékezés, szájnyálkahártyájának, bőrének kékes elszíneződése miatt. A beteg aznap reggel szexuális kontaktus kapcsán „Rush poppert” szippantott. Rendszeresen lozartánt, amlodipint, omeprazolt, aszpirint, allopurinolt, finaszteridet, szildenafilt szedett. Felvételekor éber, orientált volt, fáradékonyságról panaszkodott. Fizikális vizsgálata során kissé magasabb vérnyomáson (166/90 Hgmm), tachycardián (105/perc), a nyálkahártyák, a sclera és a végtagok acralis részeinek kékes elszíneződésén kívül egyéb eltérést nem észleltünk. A beteg artériásvérgáz-vizsgálata kielégítő oxigénellátást, normális ion-, sav-bázis háztartást, vércukorértéket mutatott (1. táblázat), methemoglobin (metHb)-szintje azonban 16,4\% volt. Az EKG-n sinustachycardia látszott, repolarizációs eltérés nem mutatkozott. Oxigén adása, tüneti kezelés

1. táblázat |A betegek felvételi artériásvérgáz-vizsgálata során észlelt értékek

\begin{tabular}{lcc}
\hline Vérgázparaméterek & Első eset & Második eset \\
\hline $\mathrm{pH}$ & 7,433 & 7,361 \\
$\mathrm{SaO}_{2}(\%)$ & 94,4 & 100 \\
$\mathrm{pCO}_{2}(\mathrm{Hgmm})$ & 34,6 & 37,2 \\
$\mathrm{pO}_{2}(\mathrm{Hgmm})$ & 73,2 & 278,6 \\
$\mathrm{cHCO}_{3}^{-}(\mathrm{mmol} / \mathrm{l})$ & 22,6 & 20,6 \\
$\mathrm{BE}(\mathrm{mmol} / \mathrm{l})$ & -1 & $-4,24$ \\
Vércukor $(\mathrm{mmol} / \mathrm{l})$ & 6,1 & 5,6 \\
Laktát $(\mathrm{mmol} / \mathrm{l})$ & $\mathrm{n} . \mathrm{a}$. & 4,2 \\
Nátrium $(\mathrm{mmol} / \mathrm{l})$ & 146,5 & 134,4 \\
Kálium $(\mathrm{mmol} / \mathrm{l})$ & 4,19 & 3,64 \\
tHb $(\mathrm{g} / \mathrm{dl})$ & 14,4 & 14 \\
$\mathrm{COHb}(\%)$ & 0,8 & 0,7 \\
$\mathrm{MetHb}(\%)$ & 16,4 & 57 \\
\hline
\end{tabular}

$\mathrm{BE}=$ bázisfelesleg; $\mathrm{CHCO}_{3}{ }^{-}=$bikarbonátkoncentráció $; \mathrm{COHb}=$ karboxihemoglobin; MetHb = methemoglobin; $\mathrm{n}$. a. = nincs adat; $\mathrm{pCO}_{2}$ = szén-dioxid parciális nyomása; $\mathrm{pH}$-érték = bármely folyadék (köztük a testnedvek) sav- és lúgháztartását jelző mérőszám; $\mathrm{pO}_{2}=$ oxigén parciális nyomása; $\mathrm{SaO}_{2}=\mathrm{az}$ artériás vér oxigénszaturációja; $\mathrm{tHb}=$ teljes hemoglobin 
mellett a beteg metHb-értéke spontán, fokozatosan csökkent ( 1 óra múlva 10,3\%, 3 óra múlva $5,1 \%, 5$ és fél óra múlva $2 \%, 7$ óra múlva 1,4\%). Felvételét követően 7 órával panaszmentesen távozott az osztályról. A másnapi kontroll során is panaszmentes volt, laborvizsgálatában máj-, vesefunkció zavart, vérképeltérést nem észleltünk.

\section{Második eset}

A 35 éves, pszichiátriai kezelés alatt álló, rendszeresen drogot, nyugtatókat és alkoholt abuzáló férfit éjjel közterületről szállították osztályunkra. A helyszínen kollabált, de sérülés nem érte. Felvételekor éber, kissé meglassult volt, szédülésről panaszkodott. Vérnyomása 122/84 Hgmm, pulzusa szapora, de ritmusos (105/perc), pulzoximéterrel mért oxigénszaturációja nem visszalégző maszkon át adott oxigén (9 liter/perc) mellett $82 \%$ volt. Állítása szerint alkoholt fogyasztott, „Rush”-t szívott, és ivott is belőle egy keveset. Fizikális vizsgálata során alkoholos leheletet, sápadt bőrt, cyanoticus nyálkahártyákat, a végtagok acralis részeinek szürkéskék elszíneződését észleltük (1. ábra), a szív és a tüdők felett kóros nem hallatszott. EKG-ján sinustachycardia látszott. Jelentős cyanosisa ellenére jó általános állapotú volt. Artériásvérgáz-vizsgálata - a sötét, inkább vénás vérnek tűnő minta (2. ábra) ellenére - jó oxigénellátást, enyhe kompenzált laktátacidózist és $57 \%$-os metHb-szintet mutatott (1. táblázat). $100 \mathrm{mg}$ metilénkék iv. adását követően cyanosisa megszünt, metHb-szintje 2,4\%-ra csökkent. A reggeli kontroll során methaemoglobinaemiája nem tért vissza (metHb: 1\%), laborvizsgálataiban az emelkedett szérumtranszaminázokon (GOT: 191 U/1, GPT: 111 U/1) kívül egyéb eltérést nem találtunk. Panaszmentesen távozott osztályunkról.

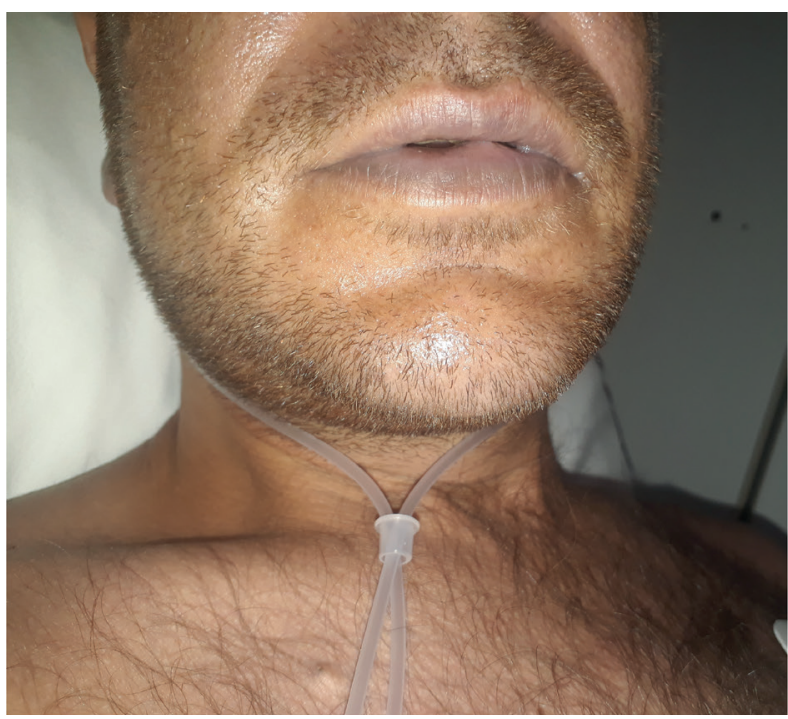

a)

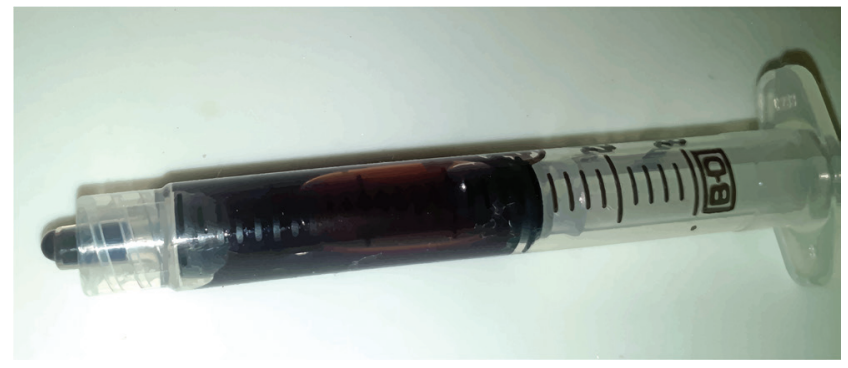

2. ábra $\quad$ A második beteg artériásvérgáz-vizsgálat céljából levett, sötét színú vére

\section{Megbeszélés}

A nitrát- és nitritszármazékok methaemoglobinaemiát okozó hatása régóta ismert. A „popperek” első képviselőjét, az amil-nitritet ma is alkalmazzák mesterséges methaemoglobinaemia előidézésére ciánmérgezés kezelése során [1]. A butil-nitrit methaemoglobinaemiát okozó hatását 1979-ben Horne és mtsai közölték először egy 25 éves, részleges NADH-metHb-reduktáz-hiányban szenvedő férfinél, de egészséges önkénteseknél is szubklinikus methaemoglobinaemiát észleltek 12 perces inhalációját követően [3]. Az illékony alkil-nitrit-származékokat korábban „alacsony rizikójú” szerként tartották számon [15], azonban súlyos, időnként fatális kimenetelű methaemoglobinaemiát okozó hatásukkal kapcsolatban több esetleírás, esetszéria is megjelent [3, 5-7, 9-14]. 2010-ben Hunter és kollégái 25, illékony nitritszármazékok által okozott methaemoglobinaemiával kapcsolatos közleményt gyüjtöttek össze. Az esetek közül 3 fatális kimenetelü volt $[8]$.

A „popperek” okozta methaemoglobinaemia előfordulási gyakoriságát illetően nincsenek pontos adatok. Az egyszeri, rövid ideig tartó inhaláció ritkán okoz súlyos

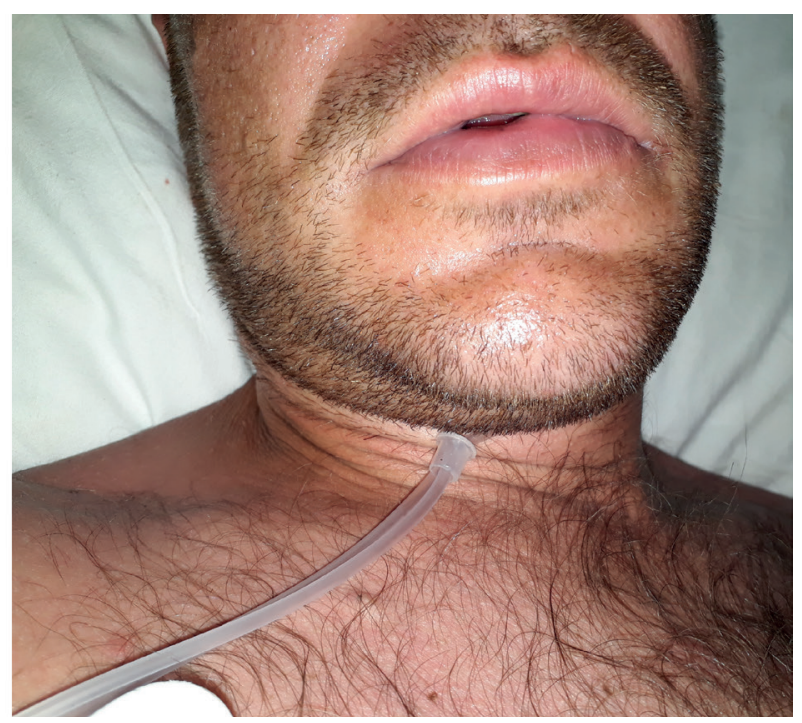

b)

1. ábra $\quad$ A methaemoglobinaemiás beteg jellegzetes ajakcyanosisa és sápadt, szürkés bőrszíne a metilénkék beadása előtt (a), a beteg normál ajak- és bőrszínének visszatérése a metilénkék beadását követően (b) második betegünknél 
methaemoglobinaemiát, így az enyhe esetek feltehetően spontán rendeződnek, és nem kerülnek az egészségügy látókörébe. Az inhaláció időtartama, gyakorisága, illetve a használó társbetegségei azonban jelentősen befolyásolhatják a súlyosságot $[3,4,6,7]$. Lenyelésük komolyabb, időnként életveszélyes methaemoglobinaemiához vezethet [8-13]. Intravénás alkalmazásukkal kapcsolatban eddig egy esetet közöltek, így ezzel kapcsolatban kevés a tapasztalat [14]. A nitritszármazékok kimutatása nehézkes, a diagnózis az anamnézisen (kiváltó noxa) és a következményes methaemoglobinaemia igazolásán alapul.

\section{Methaemoglobinaemia}

Az oxigénszállításhoz a hemoglobin $(\mathrm{Hb})$ protoporfiringyürüjében ferro $\left(\mathrm{Fe}^{2+}\right)$ állapotú vasra van szükség, mert az oxidált állapotú ferrivasat $\left(\mathrm{Fe}^{3+}\right)$ tartalmazó metHb nem képes az oxigén szállítására. Az oxigéntranszport során a ferrovas $\left(\mathrm{Fe}^{2+}\right)$ elektront ad át az oxigénnek, miközben szuperoxid $\mathrm{Fe}^{3+} \mathrm{O}_{2}{ }^{--}$keletkezik. Az oxigén leadását követően a ferroállapot $\left(\mathrm{Fe}^{2+}\right)$ helyreáll. Kis százalékban azonban az oxigén a megosztott elektronnal együtt szabadul fel, és a vas ferriállapotban $\left(\mathrm{Fe}^{3+}\right)$ marad. Fiziológiás körülmények között ez kevesebb mint 1\% (ún. élettani methaemoglobinaemia). Ennek az alacsony metHb-szintnek a fenntartásáért két enzim felelős (3. ábra). A metHb redukcióját 95\%-ban a NADHcitokróm-b5-reduktáz végzi. A másik enzim, a NADPHmetHb-reduktáz aktivitása fiziológiás körülmények között minimális, de jelentős methaemoglobinaemia esetén, bizonyos külső ágensek (például metilénkék) jelenlétében aktivitása nő. A ferrivas $\left(\mathrm{Fe}^{3+}\right)$ egy része nem enzimatikus úton is redukálódhat, aszkorbinsav vagy redukált glutation hatására, de ez lassabb és kisebb jelentőségü folyamat $[16,17]$.

Methaemoglobinaemiáról akkor beszélünk, ha a vér metHb-tartalma meghaladja a fiziológiás 1\%-ot. Veleszületett formáit a Hb strukturális abnormalitása vagy a
2. táblázat A veleszületett methaemoglobinaemia okai és típusai

\section{A hemoglobin strukturális abnormalitása}

Hemoglobin-M $(A D)$ - aminosavcsere (általában hisztidin-tirozin) a polipeptidláncban

- Heterozigóta forma (metHb: 20-30\%) - súlyos cyanosis ellenére tünetmentes

- Homozigóta forma (feltehetően az élettel összeegyeztethetetlen)

A methemoglobin redukciójáért felelős enzimek elégtelensége

- NADH-citokróm-b5-reduktáz-hiány (AR)

(4 hónapos kor alatt fiziológiásan is csökkent az enzim aktivitása *)

- Heterozigóta forma (metHb: 2-3\%)

- Homozigóta forma (metHb: 10-50\%)

Típusai:

- I-es típus (vörösvérsejtek enzimhiánya): cyanosis és enyhe tünetek, (fejfájás, fáradékonyság, terhelésre jelentkező nehézlégzés) jó életkilátások

- II-es típus (generalizált enzimhiány): microcephalia, súlyos neurológiai tünetek, mentális retardáció, táplálási nehézségek, növekedési zavar, korai halálozás

(Egyéb típusait csak néhány esetben írták le.)

- NADPH-methemoglobin-reduktáz-hiány-nem okoz methaemoglobinaemiát

$\mathrm{AD}=$ autoszomális domináns (öröklődés); $\mathrm{AR}=$ autoszomális recesszív (öröklődés); metHb = methemoglobin; $\mathrm{NADH}=$ nikotinamid-adenindinukleotid redukált formája; NADPH = nikotinamid-adenin-dinukleotid-foszfát redukált formája

*Fiatal csecsemók rizikója részben emiatt különösen fokozott a methaemoglobinaemiát okozó ágensekre (például magas nitráttartamú víz, zöldségek)

metHb redukciójához szükséges enzimek hiánya (2. táblázat) okozza [16-18]. Az enyhe, veleszületett formák időnként csak felnőttkorban, provokáló tényezők hatására manifesztálódnak, vagy egyéb panaszok miatt végzett kivizsgálás során kerülnek felismerésre [3, 6, 7, 19]. A szerzett formák gyakrabban fordulnak elö. Számos vegyület, gyógyszer (például nitritek, nitrátok, klorátok, bromátok, helyi érzéstelenítők, antibakteriális szerek, analgetikumok, anilinfestékek, nitrobenzol-származékok stb.) képes direkt vagy indirekt módon, illetve biokémiai átalakulás révén a $\mathrm{Hb}$ oxidációjára $[16,17,20]$. Az alkil-

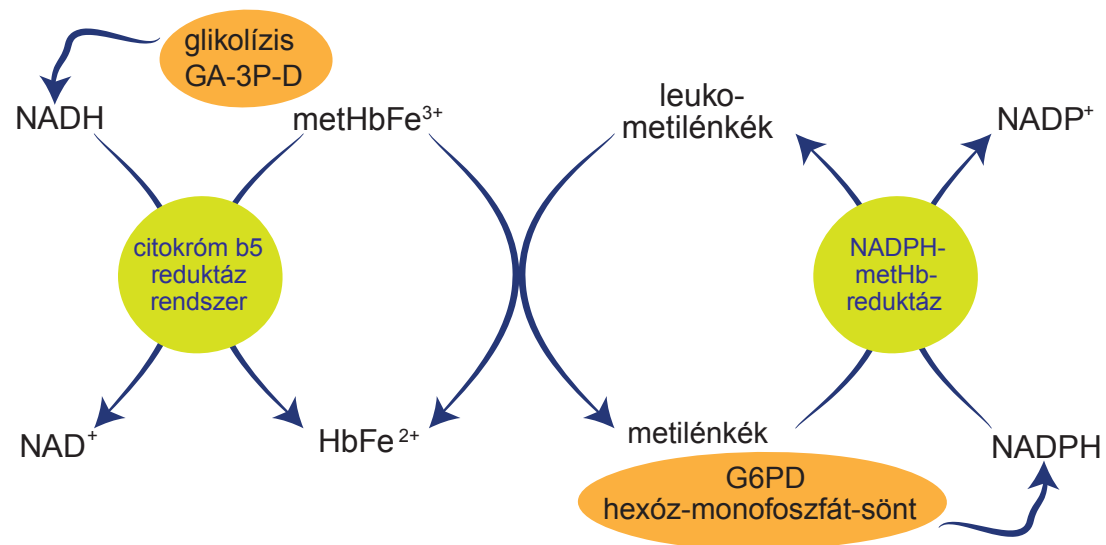

3. ábra

A

A methemoglobin redukciója

$\mathrm{Hb}=$ hemoglobin; $\mathrm{NAD}^{+} / \mathrm{NADH}=$ nikotinamid-adenin-dinukleotid/annak redukált formája; $\mathrm{NADP}^{+} / \mathrm{NADPH}=$ nikotinamid-adenin-dinukleotidfoszfát/annak redukált formája; G6PD = glükóz-6-foszfát-dehidrogenáz; GA-3PD = glicerinaldehid-3-foszfát-dehidrogenáz 
nitrit-származékok oxigén jelenlétében indirekt módon, többlépcsős sztöchiometrikus folyamat során oxidálják a Hb-ban található ferrovasat [20], de haemolysist is okozhatnak $[6,17]$.

A methaemoglobinaemia klinikai tünetei a szöveti oxigénhiány (relatív anaemia) következtében jönnek létre. A metHb alkalmatlan az oxigén szállítására, illetve a tetramer Hb-molekula nem mindegyik alegysége oxidálódik, és a keletkező hibrid molekulák nem oxidált részeinek oxigénaffinitása fokozódik, ami a szöveti oxigén leadásának további csökkenéséhez (az oxigéndisszociációs görbe balra tolódásához) vezet [16].

A methaemoglobinaemia legjellegzetesebb tünete a cyanosis (centrális és perifériás), amely általában $1,5 \mathrm{~g} / \mathrm{dl}$ (>10\%) feletti metHb-szintnél jelenik meg [16, 17, 20, 21]. Enyhe esetekben az egyetlen figyelemfelhívó jel lehet. A metHb-szint emelkedésével a tünetek súlyossága fokozódik (3. táblázat). A másik jellegzetes eltérés a metHb felszaporodása következtében a beteg vérének sötét, barnás színe (ún. „csokoládévér”), amely oxigén hatására sem változik (2. ábra). A methaemoglobinaemiás betegek vérszíne alapján létrehozott színskálát - egyéb diagnosztikus eszközök hiányában - ágy melletti gyorstesztként is alkalmazzák [22].

A pulzoximetria - fóként vérgázvizsgálattal együtt alkalmazva - fontos módszer a methaemoglobinaemia gyanújának felvetésében [23]. Múködése azon az elven alapul, hogy az oxihemoglobin $\left(\mathrm{O}_{2} \mathrm{Hb}\right)$ és a deoxihemoglobin (HHb) különböző mértékben abszorbeálja a $660 \mathrm{~nm}$-es vörös (V-) és a $940 \mathrm{~nm}$-es infravörös (IV-) fényt. $\mathrm{Az} \mathrm{IV}$-fényt az $\mathrm{O}_{2} \mathrm{Hb}$, a $\mathrm{V}$-fényt a $\mathrm{HHb}$ nyeli el nagyobb mértékben. Az eszköz a kétféle hullámhosszúságú fény abszorbciójának (A) kettős hányadosa $(\mathrm{H})$
3. táblázat |A methemoglobinszint és a klinikai tünetek megjelenése [17]

\begin{tabular}{|c|c|}
\hline Methemoglobinszint (\%)* & Tünetek \\
\hline $1-3$ & Nincs \\
\hline $3-15$ & $\begin{array}{l}\text { Sokszor tünetmentes } \\
\text { Alacsony } \mathrm{SpO}_{2} \\
\text { Palaszürke bőrszín }\end{array}$ \\
\hline $15-20$ & $\begin{array}{l}\text { Cyanosis } \\
\text { Enyhe tünetek } \\
\text { Ún. „csokoládévér” }\end{array}$ \\
\hline $20-50$ & $\begin{array}{l}\text { Szédülés, syncope } \\
\text { Nehézlégzés } \\
\text { Csökkent terhelhetőség } \\
\text { Fáradékonyság } \\
\text { Fejfájás } \\
\text { Gyengeség }\end{array}$ \\
\hline $50-70$ & $\begin{array}{l}\text { Központi idegrendszeri depresszió } \\
\text { tünetei } \\
\text { Kóma } \\
\text { Ritmuszavarok } \\
\text { Tachypnoe } \\
\text { Metabolikus acidosis } \\
\text { Epilepsziás roham }\end{array}$ \\
\hline$>70$ & $\begin{array}{l}\text { Súlyos oxigénhiányos tünetek } \\
\text { Halál }\end{array}$ \\
\hline
\end{tabular}

*A fenti értékek a normális $15 \mathrm{~g} / \mathrm{dl}$-es hemoglobinszint százalékában értendők. Az oxigénszállítást befolyásoló alapbetegségek (például anaemia, szív- és tüdőbetegségek, társuló szén-monoxid-mérgezés) esetén adott methemoglobinszint mellett a tünetek súlyosabbak lehetnek

alapján $\left(\mathrm{H}=\left[\mathrm{A}_{\mathrm{VP}} / \mathrm{A}_{\mathrm{VNP}}\right] /\left[\mathrm{A}_{\mathrm{IVP}} / \mathrm{A}_{\mathrm{IVNP}}\right]\right.$, ahol a $\mathrm{P}$ az artériás vérvolumen pulzatilis abszorbciója, az NP pedig a vénák, kapillárisok, szövetek nem pulzatilis abszorbciója) számítja ki - egészséges önkénteseken végzett kalibrációt követően - a pulzoximéterrel mért oxigénszaturá-

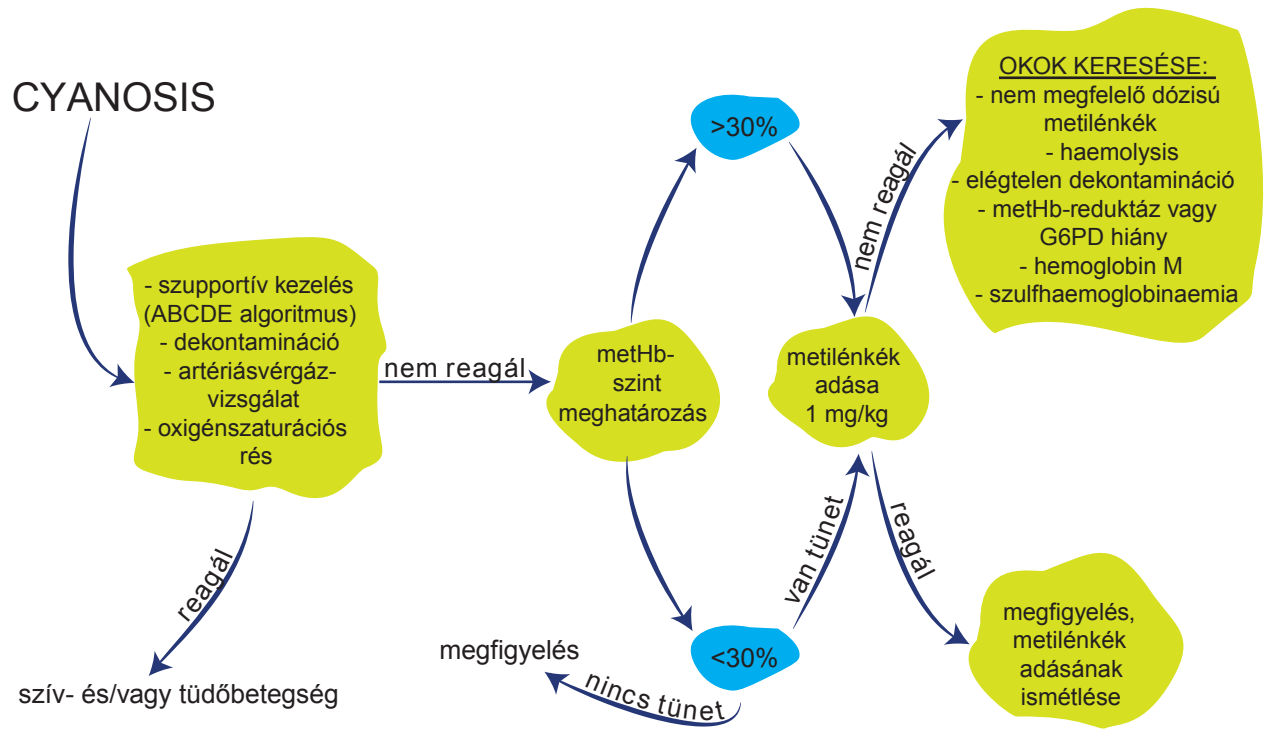

4. ábra

A methaemoglobinaemia diagnózisa és kezelése

$\mathrm{ABCDE}=$ légút, légzés, keringés, neurológia, egész test/eset; metHb = methemoglobin; G6PD = glükóz-6-foszfát-dehidrogenáz

Hajlamosító tényezők: csecsemő-, illetve időskor, anaemia, acidosis, hasmenés, veseelégtelenség, alultápláltság, szepszis, kórházi kezelés, oxidálószerek együttes alkalmazása, xenobiotikumok 
ciót $\left(\mathrm{SpO}_{2}\right)$. A metHb közel ugyanolyan mértékben abszorbeálja a V-, mint az IV-fényt, így metHb jelenlétében (fóként magas 30-35\% feletti szint esetén) a kétféle hullámhosszúságú fény abszorbciója közel egyenlő lesz. A hányados 1 körüli értéke $80-85 \%$ közötti $\mathrm{SpO}_{2}$-nek felel meg, és $\mathrm{O}_{2}$ adásával nem befolyásolható $[5,10-13]$. A methaemoglobinaemiás beteg artériásvérgáz-vizsgálata azonban az alacsony $\mathrm{SpO}_{2}$ ellenére - egyéb ok hiányában - jó oxigénszaturációt $\left(\mathrm{SaO}_{2}\right)$ mutat. A vérgázvizsgálat ugyanis az oxigén parciális nyomása alapján számítja az oxigénszaturációt. $\mathrm{Az} \mathrm{SaO}_{2}-\mathrm{SpO}_{2}$ különbsége az oxigénszaturációs rés, melynek $5 \%$ feletti értéke methaemoglobinaemiát jelezhet. Súlyos esetben a vérgázvizsgálaton laktátacidózis (1. táblázat) is észlelhető $[5,10-12,14]$.

A methaemoglobinaemia diagnózisa co-oximetriás vizsgálattal történik. A co-oximéter egy spektrofotométer, amely különböző hullámhosszúságú fények segítségével képes a vérben lévő Hb-ok (oxi-, deoxi-, karboxi-, szulf-, methemoglobin) meghatározására. Ma már a legtöbb vérgázvizsgáló készülékben megtalálható. A methaemoglobinaemia egyéb, cyanosissal járó betegségektől való elkülönítését a 4 . ábra szemlélteti.

A szerzett methaemoglobinaemia kezelésének három alappillére a tüneti terápia (oxigén adása, légútbiztosítás, lélegeztetés, a keringés stabilizálása, a görcsrohamok kezelése, az ion- és sav-bázis zavarok rendezése), a dekontamináció (a betegnek a légtérból való eltávolítása, a bőr lemosása, gyomormosás) és az antidotum-kezelés [16, 17, 20]. A methaemoglobinaemia okát, az expozíció módját mindenképp tisztázni kell, hiszen ez befolyásolhatja a terápiát.

A veleszületett formákhoz hasonlóan - amelyeknél a betegek sokszor nagyobb metHb-szinteket is tünet nélkül tolerálnak - szerzett methaemoglobinaemiában sem szükséges minden esetben antidotum-kezelés. A spontán metHb-Hb átalakulás mértéke óránként 15\%, így enyhe esetekben, normális enzimmúködések esetén, ha nincs folyamatos felszívódás és képződés, a methaemoglobinaemia spontán rendeződése várható [16]. Első esetünkben is ez történt.

Magas metHb-szint (>30\%) esetén antidotum-kezelés javasolt, de szöveti oxigén hiányára utaló tünetek (3. táblázat), az oxigénszállító kapacitást befolyásoló alapbetegségek esetén ennél alacsonyabb szinteknél is szükség lehet antidotum adására (4. ábra). Antidotumként oxidáló hatású tiazinfestékeket (metilénkék, toluidinkék) alkalmaznak $[16,17,20]$.Ametilénkék (methylthioninum chloratum) a leginkább elterjedt. Múködéséhez a glükóz-6-foszfát-dehidrogenáz (G6PD) enzim által biztosított NADPH szükséges (3. ábra). Az enzim hiányában a metilénkék-kezelés hatástalan lehet, illetve oxidáló hatása következtében maga a festék is paradox methaemoglobinaemiát és haemolysist okozhat. A G6PD-hiány legtöbbször részleges, így egyes munkacsoportok ismert G6PD-hiány vagy annak gyanúja esetén is metilénkék

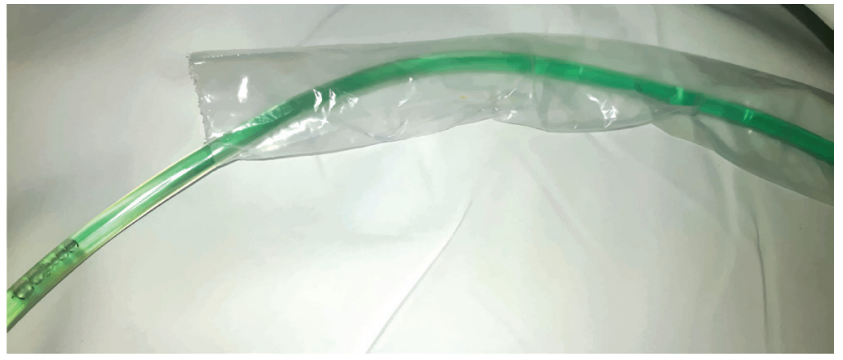

5. ábra

Metilénkék adását követően a beteg vizeletének zöld elszíneződése a hólyagkatéter csövében

adását javasolják, de alacsonyabb $(0,3-0,5 \mathrm{mg} / \mathrm{kg})$ dózisban [16].

A metilénkék adagja felnőtteknél intravénásan 1-2 $\mathrm{mg} / \mathrm{kg} 5$ perc alatt. Hatása 30 perc alatt létrejön, de nem kellő hatás esetén 1 óra múlva ismételhető. Javasolt maximális dózisa $7 \mathrm{mg} / \mathrm{kg}$. A metilénkék abszorbciós csúcsa a V-fényéhez közel, 668 nm-en van, így intravénás beadásakor - a methaemoglobinaemia fokozódásához hasonlóan - a pulzoximéter alacsony $\mathrm{SpO}_{2}$-értéket jelez. A beadás helyén irritációt, fájdalmat, nehézlégzést, tachypnoét, mellkasi diszkomfortot, a szájban és a gyomorban égő érzést, a bőr és a nyálkahártyák kékes elszíneződését, érzészavart, nyugtalanságot, félelmet, tremort, hányingert, dysuriát, izgatottságot, szerotonerg szerekkel együtt alkalmazva - monoaminoxidáz-gátló hatása (fóként a MAO-A) következtében - szerotoninszindrómát [24] okozhat. Egy része a vizelettel ürül, jellegzetesen kékeszöldre színezve azt (5. ábra).

Metilénkék hiányában, illetve annak ellenjavallata vagy hatástalansága (például G6PD-hiány, haemolysis) esetén egyéb alternatív lehetőségek (aszkorbinsav, riboflavin, hiperbárikusoxigén-kezelés, vércsere, plazmaferézis) is szóba jönnek, akár kombinált formában [22, 25, 26, 28-30]. N-acetil-ciszteinnel (NAC) mint glutationprekurzorral és antioxidánssal is történtek vizsgálatok, de nem bizonyult hatékonynak [26, 27].

\section{A „popperek" egyéb hatásai}

Az alkil-nitrit-származékok a keletkező nitrogén-monoxid (NO), ciklikus 3'-5'-guanozin -monofoszfát (cGMP) szintjének emelkedése révén relaxálják a simaizmokat [31], kipirulást, fejfájást, szédülést, vérnyomáscsökkenést, tachycardiát, kollapszust $[4,5,8,10-14]$ okozhatnak. Lazítják a végbél záróizmait is, emiatt közkedveltek a homo- és biszexuális férfiak körében [1]. A cGMP szintjét emelő gyógyszerek (például PDE-gátlók) szedése mellett simaizom-lazító hatásuk fokozódhat, jelentős vérnyomásesést okozhatnak. (Első esetünkben a beteg PDE5-gátló szildenafilt szedett, de ennek klinikai következménye nem volt.) A metilénkék gátolja a nitrogénoxid-szintetázt és a guanilát-ciklázt a vascularis simaizomban, így csökkentheti az alkil-nitrit-származékok következtében fellépő hypotensiót is $[10,32]$. 
A „popperek” irritálják a nyálkahártyákat és a bőrt, belégzésük során köhögést, fulladást [4] okozhatnak, a bőrrel való érintkezésükkor kontaktdermatitises elváltozások [33-35], differenciáldiagnosztikai problémát okozó fekélyek jelenhetnek meg [36], de gyomor-bél rendszeri tünetek, hányinger, hányás, hasi fájdalom is elöfordulhat [9].

A „poppereket” évtizedek óta használják, de csak az elmúlt években figyeltek fel látáskárosító, maculopathiát okozó hatásukra [37-40]. Hátterében a diagnosztika jelentős fejlődése (például az optikaikoherencia-tomográfia [OCT] megjelenése) mellett a szerek összetételében bekövetkező változásokat feltételezik. 2006-ban az izobutil-nitrit karcinogénné nyilvánítását követően többen látásromlást jeleztek azok közül, akik az izobutil-nitritszármazékokat az izopropil-nitrit-származékokra cserélték [37, 38]. A használók hasonló panaszokat (a centrális látás károsodása, homályos látás, szikralátás, fényérzékenység) említettek. A tünetek gyorsan (néhány óra-nap múlva) jelentkeztek, rendszeres, de akár egyszeri használatot követően is előfordultak. A vizsgálatok során a látásélesség enyhe vagy mérsékelt csökkenését, OCT-val a subfoveolaris régióban a retina külső/belső szegment találkozásának szakadását, foveolaris hipo-, hiperreflektivitást, oftalmoszkópiával finom sárga lerakódásokat észleltek a foveolában [38-40]. Az elváltozások általában mindkét szemet érintették, de féloldaliakat is leírtak. Hui és kollégái a rendszeres használóknál súlyosabb léziókat tapasztaltak [39]. A szerek használatának felfüggesztését követően az esetek egy részében (még krónikus használók esetén is) javulást láttak, míg más esetekben ezt nem tapasztalták [37-39]. Clemens és mtsai elektroretinográfiás vizsgálatok során diffúz, nemcsak a maculára lokalizálódó elváltozásokat észleltek, emiatt maculopathia helyett újabban a „popperek” okozta retinopathia elnevezést javasolják [40]. A szemtünetek prevalenciájának megítélése, a betegek követése nehéz. A Global Drog Survey 2012. évi online felmérése szerint az egy éven belül „poppereket” használók körében azok közül, akik azt állították, hogy a szerek befolyásolták vagy befolyásolhatták a látásukat, mindössze 19-en (11,9\%) fordultak szakemberhez, és csak hárman vallották be az alkil-nitritszármazékok használatát [37]. A szemtünetek oka tisztázatlan. Hátterükben a nitritek által okozott nitrogénoxid-szintetáz up-regulációt és a túltermelődő NO toxikus hatását feltételezik [38, 39]. Jelenleg speciális kezelés nem áll rendelkezésre, de a használat felfüggesztése jótékony hatású lehet [39].

\section{Következtetés}

Az illékony alkil-nitrit-származékok, az ún. „popperek” használatának veszélyes szövődménye a methaemoglobinaemia. Inhalációjuk, lenyelésük és intravénás alkalmazásuk is methaemoglobinaemiát okozhat. Az oxigén adására nem javuló cyanosis, a vér sötét színe és a magas oxigénszaturációs rés már az első vizsgálat során felvet- heti a methaemoglobinaemia gyanúját, ami co-oximetriás (vérgáz-) vizsgálattal igazolható, és a kiváltó ok (például alkil-nitritek) is kideríthető. A kezelés a tüneti terápia és a dekontamináció mellett antidotum (metilénkék) adásán alapul, amit a metHb-szint mellett a beteg tünetei és társbetegségei is befolyásolnak. A „popperek” szem- és börtüneteket is okozhatnak, emiatt tisztázatlan okú retino-/maculopathia, irritatív bőrelváltozások, fekélyek differenciáldiagnosztikája során az alkil-nitritszármazékok használata felől is érdemes tájékozódni.

Anyagi támogatás: A közlemény megírása, illetve a kapcsolódó kutatómunka anyagi támogatásban nem részesült.

Szerzői munkamegosztás: B. Á.: A kézirat megírása, szerkesztése, adatgyứjtés, a második beteg kezelésében részt vevő belgyógyász. B. A.: A kézirat szerkesztése, az első beteget kezelő belgyógyász. A cikk végleges változatát mindkét szerző elolvasta és jóváhagyta.

Érdekeltségek: A szerzőknek nincsenek érdekeltségeik.

\section{Irodalom}

[1] Romanelli F, Smith KM, Thornton AC, et al. Poppers: epidemiology and clinical management of inhaled nitrit abuse. Pharmacotherapy 2004; 24: 69-78.

[2] Wu LT, Schlenger WE, Ringwalt CL. Use of nitrite inhalants („poppers”) among American youth. J Adolesc Health 2005; 37: 52-60.

[3] Horne MK 3rd, Waterman MR, Simon LM, et al. Methemoglobinemia from sniffing butyl nitrite. Ann Intern Med. 1979; 91: 417-418

[4] Bladberry SM, Whittington RM, Parry DA, et al. Fatal methaemoglobinemia due to inhalation of isobutyl nitrite. J Toxicol Clin Toxicol. 1994; 32: 179-184.

[5] Faley B, Chase H. A case of severe amyl nitrite induced methe moglobinemia managed with methylene blue. J Clinic Toxicol. 2012; 2: 127 .

[6] Graves TD, Mitchell S. Acute haemolytic anaemia after inhala tion of amyl nitrite. J R Soc Med. 2003; 96: 594-595.

[7] Wong A, Koutsogiannis Z, Greene S, et al. A case of hemolysis and methaemoglobinemia following amyl nitrite use in an individual with G6PD deficiency. J Acute Med. 2013; 3: 23-25.

[8] Hunter L, Gordge L, Dargan PI, et al. Methaemoglobinaemia associated with the use of cocaine and volatile nitrites as recreational drugs: a rewiev. Br J Clin Pharmacol. 2011; 72: 18-26.

[9] Pain S, Chavant F, Fauconneau B, et al. Dangerous intoxication after oral ingestion of poppers (alkyl nitrites): two case reports. Therapie 2017; 72: 397-399.

[10] Behouche A, Chapuis C, Albaladejo P, et al. Intoxication by massive ingestion of poppers: a case report. J Clin Toxicol. 2019; 9: 3.

[11] Lefevre T, Nuzzo A, Mégarbane B. Poppers-induced life-threatening methemoglobinemia. Am J Respir Crit Care Med. 2018; 198: e137-el38

[12] Batista F, Alves C, Trindade M, et al. Methaemoglobinemia in duced by poppers and bupropion intoxication in the emergency department. Eur J Case Rep Intern Med. 2019; 6: 001072.

[13] Al-Lawati A, Murch N. Acquired methemoglobinaemia. Sultan Qaboos Univ Med J. 2012; 12: 237-241 
[14] Reisinger A, Vogt S, Essl A, et al. Lessons of the months 3: intravenous poppers abuse: case report, management and possible complication. Clin Med. 2020; 20: 221-223.

[15] Nutt D, King LA, Saulsbury W, et al. Development of rational scale to assess the harm of drugs of potential misuse. Lancet 2007; 369: 1047-1053.

[16] Wright RO, Lewander WJ, Woolf AD. Methemoglobinemia: etiology, pharmacology, and clinical management. Ann Emerg Med. 1999; 34: 646-656.

[17] Price DP. Methemoglobin inducers. In: Nelson LN, Hoffman R, Howland MA, et al. (eds.) Goldfrank's toxicologic emergencies. 1lth edn. McGraw-Hill Education, New York, NY, 2019; pp. 1703-1712.

[18] Percy MJ, Lappin TR. Recessive congenital methaemoglobinaemia: cytochrome b5 reductase deficiency. Br J Haematol. 2008; 141: 298-308.

[19] Yamaji F, Soeda A, Shibata H, et al. A new mutation of congenital methemoglobinemia exacerbated after methylene blue treatment. Acute Med Surg. 2018; 5: 199-201.

[20] Bradberry SM. Occupational methaemoglobinaemia. Mechanism of production, features, diagnosis and management including the use of methylene blue. Toxicol Rev. 2003; 22: 13-27.

[21] Pap Cs. Hemoglobin toxins and poisonous gases. In: Tulassay Zs. (ed.) Clinical internal medicine. [Vérmérgek és mérgező gázok. In: Tulassay Zs. (szerk.) Klinikai belgyógyászat.] Medicina Könyvkiadó, Budapest, 2017; pp. 800-803. [Hungarian]

[22] Shihana F, Dawson AH, Dobbins T, et al. A bedside test for methaemoglobinemia improved antidote use in propanil poisoning. Clin Toxicol (Phila) 2016; 54: 576-580.

[23] Chan ED, Chan MM, Chan MM. Pulse oximetry understanding its basic principles facilitates appreciation of its limitations. Respir Med. 2013; 107: 789-799.

[24] Ramsay RR, Dunford C, Gillmann PK. Methylene blue and serotonin toxicity: inhibition of monoamine oxidase A (MAO A) confirms a theoretical prediction. Br J Pharmacol. 2007; 152: 946-951.

[25] Rino PB, Scolnik D, Fustiñana A, et al. Ascorbic acid for the treatment of methemoglobinemia: the experience of a large tertiary care pediatric hospital. Am J Ther. 2014; 21: 240-243.

[26] Dötsch J, Demirakça S, Kratz M, et al. Comparison of methylene blue, riboflavin, and $\mathrm{N}$-acetylcysteine for the reduction of nitric oxide-induced methemoglobinemia. Crit Care Med. 2000; 28: 985-961.
[27] Tanen DA, LoVecchio F, Curry SC. Failure of intravenous Nacetylcysteine to reduce methemoglobin produced by sodium nitrite in human volunteers: a randomized controlled trial. Ann Emerg Med. 2000; 35: 369-373.

[28] Dhibar DP, Sahu KK, Jain S, et al. Methemoglobinemia in a case of paint thinner intoxication, treated successfully with vitamin C. J Emerg Med. 2017; 54: 221-224.

[29] Cho Y, Park SW, Han SK, et al. A case of methemoglobinemia successfully treated with hyperbaric oxygenation monotherapy. J Emerg Med. 2017; 53: 685-687.

[30] Shatila W, Verma A, Adam S. Plasmapheresis in severe methemoglobinemia following occupational exposure. Transfus Apher Sci. 2017; 56: 341-344.

[31] Ma L, Hu L, Feng X, et al. Nitrate and nitrite in health and disease. Aging Dis. 2018; 9: 938-945.

[32] Jang DH, Nelson LS, Hoffmann RS. Methylene blue for distributive shock: a potential new use of an old antidote. J Med Toxicol. 2013; 9: 242-249.

[33] Bos JD, Jansen FC, Timmer JG. Allergic contact dermatitis to amyl nitrite („poppers”). Contact Dermatitis 1985; 12: 109.

[34] Schauber J, Herzinger T. 'Poppers' dermatitis. Clin Exp Dermatol. 2012; 37: 587-588.

[35] Moret F, Lindner G, Woitok BK. The untimely popping phial: poppers as an unusual cause of skin corrosion of the thigh. Case Rep Emerg Med. 2020; 2020: 2058624.

[36] Latini A, Lora V, Zaccarelli M, et al. Unusual presentation of poppers dermatitis. JAMA Dermatol. 2017; 153: 233-234.

[37] Davies AJ, Borschmann R, Kelly SP, et al. The prevalence of visual symptoms in poppers users: a global survey. BMJ Open Ophthalmol. 2017; 1: e000015.

[38] Rewbury R, Hughes E, Purbrick R, et al. Poppers: legal highs with questionable contents? A case series of poppers maculopathy. Br J Ophthalmol. 2017; 101: 1530-1534.

[39] Hui M, Galvin J, Chilov M, et al. Popper maculopathy: longterm follow-up and case series. Retin Cases Brief Rep. 2017; 14: 195-199.

[40] Clemens CR, Alten F, Loos D, et al. Poppers maculopathy or retinopathy? Eye $2015 ; 29: 148-149$.

(Bakos Ágnes dr., Budapest, Alsóerdősor u. 7., 1074 e-mail: agnesbakos26@gmail.com)

A cikk a Creative Commons Attribution 4.0 International License (https://creativecommons.org/licenses/by/4.0/) feltételei szerint publikált Open Access közlemény, melynek szellemében a cikk bármilyen médiumban szabadon felhasználható, megosztható és újraközölhetö, feltéve, hogy az eredeti szerző és a közlés helye, illetve a CC License linkje és az esetlegesen végrehajtott módositások feltüntetésre kerülnek. (SID_1) 